\title{
STUDY OF BITUMINOUS CONCRETE UNDER DIFFERENT MIX CONDITIONS
}

\author{
Jaswinder Singh ${ }^{1}$, Pardeep Kumar Gupta ${ }^{2}$ \\ ${ }^{1}$ Student, Department of Civil Engineering, PEC University of Technology, Chandigarh, India \\ ${ }^{2}$ Associate professor, Department of Civil Engineering, PEC University of Technology, Chandigarh, India
}

\begin{abstract}
The use of bitumen in road construction has increased many-fold throughout the world due to its compatibility, the ease in road construction and above all the advantage of allowing traffic immediately after construction. The most common binder used for road surfacing is bitumen obtained from petroleum However; Petroleum is nowadays becoming scarce due to depletion of its source. Even though bitumen is widely used in road construction, there are some drawbacks in bituminous mix like high susceptibility to temperature variation, tendency to crack, lesser effective service life etc. Therefore, bituminous pavements fail to give the expected service life under adverse climatic, environmental and traffic condition. In an attempt to enhance the service life of bituminous surfacing under adverse prevailing conditions, research is going on throughout the world in the area of additives in search of improved, durable and cost effective bituminous binders. The main objective of this study is to evaluate the properties of bituminous mixes that can be made by use of different grading of bitumen like VG10 VG30 VG40 and different grading of aggregate with using of code references.
\end{abstract}

Keywords: Bitumen, Petroleum, Susceptibility

\section{INTRODUCTION}

In India, the National Highways span about $67,000 \mathrm{~km}$, of which about $200 \mathrm{~km}$ are expressways. National highways constitute approximately $2 \%$ of the total road network of India but carry nearly $40 \%$ of the total traffic. About $65 \%$ of freight and $80 \%$ passenger traffic is carried by the roads.

Indian road network of 33 lakh $\mathrm{km}$ is second largest in the world and consist of Expressways, National Highway, State Highway, Major district roads and Rural and other roads.Number of vehicles has been growing at an average pace of $10.16 \%$ per annum over the last five years. The most common binder used for road surfacing is bitumen obtained from petroleum. However, petroleum is nowadays becoming scarce due to depletion of its sources. In addition to this, bituminous pavements have some drawbacks such as high temperature susceptibility, low temperature cracking etc which demand frequent maintenance and hence increase in life cycle cost of the pavement. Roads are mainly constructed now to use the mineral aggregate and bitumen. Even though the amount of bitumen used is very small as compared to that of mineral aggregates, the performance of the road pavement is mostly determined by the properties of the bitumen, as bitumen is the continuous phase and the only deformable component. On the other end, the increasing of traffic load continuously on the road pavements has to require maximum mechanical stability of the pavement to the good performance with conventional pure bitumen. For the achievement of the improvement, so it is very necessary for the road construction to use modified mix. There is two mains considerations of flexible pavement are the design of pavement and mix design for the pavement. The present study is related to the mix design considerations. A good design of bituminous concrete is expected to result of the mix which has adequately durable, resistance to fatigue, strong, environment friendly and economically. A mix designer has to try for the achievement of these requirements through a number of tests on the mix with varied proportions of aggregate and bitumen and finalizes with the best one. This present research has to identify some of the issues which are involved in the bituminous concrete mix design.

\section{LITERATURE REVIEW}

Brown (1994) studied on bituminous concrete and concluded that the drain down in $\mathrm{BC}$ is greatly effected by the quality of stabilizer (whether it is above or below the drain down) type of that stabilizer and the quality and type of filler.

Kamaraj et al. (2004) study the BC by wet process and dense grade bituminous mix with stone dust and lime stone as filler and he found the stability as BC mix through various tests.

Reddy et al. (2004) studied the use of rubber with 80/100 bitumen in $\mathrm{BC}$ and he concluded that the fatigue and permanent deformation and resistance to moisture characteristics are improved as compared to the normal mixes.

Ibrahim M.asi(2005) He performed various tests like marshal tests, loss of marshal stability ,tensile strength and loss of tensile strength, fatigue life were conducted on DGM and $\mathrm{BC}$. He found that the $\mathrm{BC}$ will have high compressive strength and tensile strength as compare to DGM. BC will also have higher durability, high resistance property and it can be used in hotter climate. 
Mustafa and Serdal (2007) showed that, with the use of marble dust obtained from shaping process of marble blocks and limestone as filler, and optimum moisture bitumen is determined then it shown good results in marshal stability tests.

Oduroh et al. (2000) It shows that the variation in the percentage of crushed coarse particles have significant effect on permanent deformation properties. As we decrease the crushed coarse particle, the increase in rutting potential of the HMA mixtures will be there.

\section{SCOPE AND OBJECTIVE}

\subsection{Scope}

Bituminous concrete mix consists of a mixture of aggregates which has maximum size less than $25 \mathrm{~mm}$, and the fine filler has size is less than $0.075 \mathrm{~mm}$. Optimum bitumen is added to the mix so that the compacted mix is effectively impervious, good compressive strength and elastic properties. The bituminous mix design aims to determine the proportion of coarse aggregate, fine aggregate, filler and bitumen to produce a mix which is strong, durable, workable, and economical.

\subsection{Objectives Of Study}

- To study Bituminous Concrete Mix with using the aggregate grading with different proportion of coarse aggregate and fine aggregate.

- To study BC Mix with using the different grading of bitumen like VG10, VG30 and VG40.

- To study the strength of mix using Marshall Method.

- In this method calculate the Stability Value, flow value, voids in the mix, Unit weight of the mix, voids filled with bitumen etc.

- Comparison of different mixes.

\section{EXPERIMENT AND RESULTS}

\subsection{Test of Aggregate}

Aggregates form the major portion of pavement structure and they form the prime materials used in pavement construction. Aggregate have to bear stresses occurring due to the wheel loads on the pavement and on the surface they also have to resist wear due to abrasive action of traffic. Therefore the properties of the aggregate are of considerable significance to the highway engineers.

Table-1: Test of aggregate

\begin{tabular}{|l|l|l|}
\hline TEST & $\begin{array}{l}\text { Maximum } \\
\text { value for BC } \\
\text { Mix }\end{array}$ & $\begin{array}{l}\text { Observed } \\
\text { value }\end{array}$ \\
\hline Crushing test & $30 \%$ & $15.2 \%$ \\
\hline Abrasion test & $30 \%$ & $17.4 \%$ \\
\hline Impact test & $30 \%$ & $20.8 \%$ \\
\hline Flakiness index & $15 \%$ & $9 \%$ \\
\hline Elongation index & $15 \%$ & $11 \%$ \\
\hline Water absorption & $2 \%$ & $0.8 \%$ \\
\hline
\end{tabular}

\begin{tabular}{|l|l|l|}
\hline $\begin{array}{l}\text { Specific gravity } \\
\text { (course } \\
\text { aggregate) }\end{array}$ & 2.71 \\
\hline Fine aggregate & & 2.65 \\
\hline Filler (sand) & & 2.28 \\
\hline
\end{tabular}

\subsection{Test of Bitumen}

Bitumen is available in a variety of types and grades. To judge the suitability of these binders various physical tests have been specified by agencies like ASTM, Asphalt Institute, British Standards Institution and the ISI. These tests include penetration test, ductility tests, softening point test and viscosity test.

Table-2: Test of Bitumen

\begin{tabular}{|c|c|c|c|c|c|c|}
\hline \multirow[t]{2}{*}{ Test } & \multicolumn{3}{|c|}{$\begin{array}{l}\text { Permissible } \\
\text { Value }\end{array}$} & \multicolumn{3}{|c|}{ Observed value } \\
\hline & $\begin{array}{l}\text { VG } \\
10\end{array}$ & $\begin{array}{l}\mathbf{V} \\
\mathbf{G} \\
\mathbf{3 0} \\
\end{array}$ & $\begin{array}{l}\text { VG } \\
40\end{array}$ & $\begin{array}{l}\text { VG } \\
10\end{array}$ & $\begin{array}{l}\text { VG } \\
\text { 30 }\end{array}$ & $\begin{array}{l}\text { VG } \\
40\end{array}$ \\
\hline $\begin{array}{l}\text { Softening } \\
\text { point }(\mathrm{mi} \\
\text { n. })^{0} \mathrm{C} \\
\end{array}$ & 40 & 47 & 50 & 52 & 65 & 68 \\
\hline $\begin{array}{l}\text { Ductility } \\
\text { (cm) } \\
\text { minimu } \\
\text { m value }\end{array}$ & 75 & 40 & 25 & 94 & 86.5 & 64.5 \\
\hline $\begin{array}{l}\text { Specific } \\
\text { value } \\
\text { (minimu } \\
\text { m) }\end{array}$ & $\begin{array}{l}0.9 \\
9\end{array}$ & $\begin{array}{l}0.9 \\
9\end{array}$ & 0.99 & 1.02 & 1.02 & 1.02 \\
\hline $\begin{array}{l}\text { Absolute } \\
\text { viscosity } \\
\text { (Poise) } \\
\end{array}$ & 800 & $\begin{array}{l}24 \\
00\end{array}$ & $\begin{array}{l}320 \\
0\end{array}$ & 1022 & 2558 & 3531 \\
\hline $\begin{array}{l}\text { Penetrati } \\
\text { on } \\
\text { value(m } \\
\text { m) }\end{array}$ & $\begin{array}{l}80- \\
100\end{array}$ & $\begin{array}{l}50- \\
70\end{array}$ & $\begin{array}{l}40- \\
60\end{array}$ & 86 & 67 & 36.5 \\
\hline
\end{tabular}

\subsection{Gradation of Aggregates}

Table-3: JOB MIX FORMULAE FOR BITUMINOUS CONCRETE SURFACING (25-50mm THICK)

\begin{tabular}{|l|l|l|l|l|l|}
\hline $\begin{array}{l}\text { I.S Sieve } \\
\text { Designat } \\
\text { ion }\end{array}$ & $\begin{array}{l}\text { \%age } \\
\text { passin } \\
\text { g } \\
\text { requir } \\
\text { ed }\end{array}$ & $\begin{array}{l}\text { \%age } \\
\text { Aggreg } \\
\text { ate } \\
\text { Type I }\end{array}$ & $\begin{array}{l}\text { \%age } \\
\text { Aggreg } \\
\text { ate } \\
\text { Type II }\end{array}$ & $\begin{array}{l}\text { \%age } \\
\text { Aggreg } \\
\text { ate } \\
\text { Type } \\
\text { III }\end{array}$ & $\begin{array}{l}\text { \%ag } \\
\text { e } \\
\text { passi } \\
\text { ng } \\
\text { blend }\end{array}$ \\
\hline $20 \mathrm{~mm}$ & 100 & 100 & 100 & 100 & 100 \\
\hline $13.2 \mathrm{~mm}$ & $\begin{array}{l}79- \\
100\end{array}$ & 35.6 & 96.6 & 100 & 89.8 \\
\hline $10 \mathrm{~mm}$ & $70-88$ & 5.4 & 75.3 & 100 & 79.97 \\
\hline $4.75 \mathrm{~mm}$ & $53-71$ & 2.9 & 26.4 & 97.1 & 64.16 \\
\hline $2.36 \mathrm{~mm}$ & $42-58$ & 1.2 & 36.1 & 77.5 & 47.05 \\
\hline $1.18 \mathrm{~mm}$ & $34-48$ & - & 2.2 & 59.55 & 34.98 \\
\hline
\end{tabular}




\begin{tabular}{|l|l|l|l|l|l|}
\hline $600 \mu$ & $26-38$ & - & 1.15 & 46.8 & 29.52 \\
\hline $300 \mu$ & $18-28$ & - & 1.1 & 33.2 & 20.67 \\
\hline $150 \mu$ & $12-20$ & - & 0.9 & 27.9 & 17.87 \\
\hline $75 \mu$ & $04-10$ & - & 0.23 & 10.05 & 6.80 \\
\hline
\end{tabular}

\subsection{Aggregate Blend}

Aggregate Type I $\quad 15 \%$

Aggregate Type II $25 \%$

Aggregate Type III $\quad 60 \%$

\section{RECORDS AND OBSERVATION}

\subsection{Marshall Readings for VG 10, VG 30, VG 40}

Table-4: Marshall Readings For VG 10, VG 30, VG 40

\begin{tabular}{|c|c|c|c|c|c|c|c|c|}
\hline \multicolumn{2}{|c|}{ Bitumen content } & \multirow{2}{*}{$\begin{array}{l}5.2 \\
1023.1 \\
\end{array}$} & \multirow{2}{*}{$\begin{array}{l}\mathbf{5 . 6} \\
1403.2 \\
\end{array}$} & \multirow{2}{*}{$\begin{array}{l}\mathbf{6 . 0} \\
1650.6 \\
\end{array}$} & \multirow{2}{*}{$\begin{array}{l}6.4 \\
1418.3 \\
\end{array}$} & \multirow{2}{*}{$\begin{array}{l}6.8 \\
1390.2 \\
\end{array}$} & \multirow{2}{*}{$\begin{array}{l}\text { OBC } \\
1650.6(\text { at } 6 \%)\end{array}$} & $\begin{array}{l}\text { LIMIT } \\
\text { S } \\
\end{array}$ \\
\hline \multirow{3}{*}{$\begin{array}{l}\text { Stabilit } \\
\text { y value } \\
(\mathrm{kg})\end{array}$} & VG 10 & & & & & & & \multirow[b]{3}{*}{$340 \mathrm{~kg}$} \\
\hline & VG 30 & 1334.5 & 1632.4 & 1828.3 & 1520.2 & 1475.3 & 1867.6 (at $5.8 \%$ ) & \\
\hline & VG 40 & 1580.2 & 1993.5 & 1754.8 & 1701.3 & 1678.3 & $\begin{array}{l}1993.5 \text { (at } 5.6 \\
\%)\end{array}$ & \\
\hline \multirow{3}{*}{$\begin{array}{l}\text { Flow } \\
\text { Value } \\
(\mathbf{m m})\end{array}$} & VG 10 & 2.47 & 2.71 & 3.26 & 3.68 & 3.81 & $3.26($ at $6 \%)$ & \multirow[b]{3}{*}{$2-4 \mathrm{~mm}$} \\
\hline & VG 30 & 2.36 & 2.70 & 2.95 & 3.45 & 3.62 & 2.87 (at 5.8) & \\
\hline & VG 40 & 2.12 & 2.41 & 2.82 & 3.01 & 3.17 & 2.41 (at $5.6 \%$ ) & \\
\hline \multirow{3}{*}{$\begin{array}{l}\text { Voids } \\
\text { in total } \\
\text { Mix \% }\end{array}$} & VG 10 & 5.16 & 4.70 & 3.82 & 3.52 & 3.17 & $3.82($ at $6 \%)$ & \multirow[b]{3}{*}{$3-5 \%$} \\
\hline & VG 30 & 5.28 & 4.50 & 3.91 & 3.43 & 3.03 & 4.29 (at 5.8) & \\
\hline & VG 40 & 4.72 & 4.02 & 3.56 & 3.22 & 2.76 & $4.02($ at $5.6 \%)$ & \\
\hline \multirow{3}{*}{$\begin{array}{l}\text { Voids } \\
\text { filled } \\
\text { with } \\
\text { Bitum- } \\
\text { en \% }\end{array}$} & VG 10 & 78.13 & 82.22 & 85.13 & 91.37 & 95.06 & $85.13($ at $6 \%)$ & \multirow[b]{3}{*}{$75-85 \%$} \\
\hline & VG 30 & 78.21 & 83.29 & 89.45 & 92.30 & 96.09 & 86.23 (at $5.8 \%$ ) & \\
\hline & VG 40 & 72.21 & 83.58 & 87.07 & 91.89 & 95.27 & 83.58 (at $5.6 \%$ ) & \\
\hline
\end{tabular}

\subsection{Comparison of Three Mixes}

Table-5: Comparisons of Three Mixes

\begin{tabular}{|l|l|l|l|}
\hline Properties & VG 10 & VG 30 & VG 40 \\
\hline $\begin{array}{l}\text { Marshall } \\
\text { Stability ( KG ) }\end{array}$ & 1650.6 & 1867.6 & 1993.5 \\
\hline Flow (mm) & 3.26 & 2.87 & 2.41 \\
\hline $\begin{array}{l}\text { Voids in total } \\
\text { mix \% }\end{array}$ & 3.82 & 4.29 & 4.02 \\
\hline $\begin{array}{l}\text { Voids filled with } \\
\text { bitumen \% }\end{array}$ & 85.13 & 86.23 & 83.58 \\
\hline
\end{tabular}

\section{CONCLUSION}

1. In this study the maximum stability of the mix is achieved when the bitumen used is VG 40.

2. At the OBC the voids filled with bitumen is more in the VG 30 Bitumen mix.

3. The optimum bitumen content for VG 10, VG 30 and VG 40 are $6.0 \%, 5.8 \%$ and $5.6 \%$ respectively.

4. As we increase the grade of bitumen, the flow value will be decreased.

5. At OBC the total voids in the mix is minimum for VG 10 grade bitumen mix.

\section{REFERENCES}

[1] Principles and practices of Highway Engineering by Dr. L. R. Kadyali and Dr. N.B. Lal.

[2] Ministry of Road Transport \& HighwaysSpecifications for Road and Bridge Works (fourth revision) Published by IRC.

[3] Highway Material Testing (Laboratory Manual) by S.K. Khanna and C.E.G Justo.

[4] Highway Engineering by S.K. Khanna and C.E.G. Justo.

[5] Standard specification from Ministry of roads and highways transportation.

[6] Brown E.R. and Manglorkar H. (1993), "Evaluation of Laboratory Properties of BC mixtures", NCAT Report No. 93-5, Auburn University, Alabama.

[7] Brown E.R. and Mallick R.B. (1994), "Stone Matrix Asphalt Properties Related to Mixture Design", NCAT Report 94-02.

[8] Bose S., Kamaraj C. and Nanda P.K. (2006), "Stone Mastic Asphalt (SMA) - A Long Life Pavement Surface", International Seminar on Innovations in Construction and Maintenance of Flexible Pavements, Agra, 2-4 September, Technical Papers, Volume 1, pp 169-17 
[9] Fletcher, T., Chandan, C., Masad, E., Sivakumar, K. (2002), "Measurement of Aggregate Texture and Its Influence on HMA Permanent Deformation," Journal of Testing and Evaluation, American Society for Testing and Materials, ASTM, Vol. 30, No. 6, 524-531.

[10] Huber, G.A., and Heiman, G.H. (1987) Effect of asphalt concrete parameters on rutting performance: a field investigation. Proceedings of Association of Asphalt Paving Technologists, 56, 33-61.

[11] 11. Using IRC Code : 111-2009. 